\title{
Evaluating the Protective Capacity of Aquifersat Uyoinakwaibom State, Southern Nigeria, using the Vertical Electrical Sounding(VES) Technique
}

\author{
Ekpo, A.E. ${ }^{1}$, Orakwe, L. C. ${ }^{1}$, Ekpo, F.E. ${ }^{2}$ and Eyeneka, F.D ${ }^{3}$ \\ Department of Agricultural \&Bioresources Engineering, NnamdiAzikiwe University, Awka ${ }^{1}$ \\ Department of Biological Sciences, AkwaIbom State University, IkotAkpaden, MkpatEnin ${ }^{2}$ \\ Department of Physics, AkwaIbom State College of Education, AfahaNsit, Etinan ${ }^{3}$
}

\begin{abstract}
This work entails evaluating the protective capacity of the aquifer using the Vertical Electrical method to assess the vulnerability of aquifers using resistivity parameters of the upper most geo-electric materials layer overlying the aquifer. Seventeen (17) vertical electrical sounding (VES) points were conducted at various locations within the study area. The result of the study shows that the longitudinal unit conductance values obtained from the study area ranges from 0.003864 to 0.059655 mhos. The study revealed that aquifers within the area are susceptible to pollution since the protective capacities of the aquifers are generally poor. Vulnerability map of the study area produced from the longitudinal unit conductance indicates that the North central, northeast and south central of the map shows that the vulnerability rate is better off than the others i.e. the northwest, southwest and part of the eastern side of the map. Sand layer seems to provide lower longitudinal conductance generally in the study area and hence poor protective capacity. It can be inferred from this study that sandy soils have poor protective capacity due to its pore space and lessabsorption capacity compared to clayey and shaly soils thus providing a lesser protective capacity for groundwater. The results of this study have provided reliable information about the protective capacity of the materials overlying the aquiferous unit which should be considered for planning, development, siting of prospective water resource projects and serves as a guide for groundwater pollution control in the study area.
\end{abstract}

Keywords: Vertical electrical sounding, vulnerability assessment, longitudinal conductance, protective capacity, groundwater.

\section{INTRODUCTION}

Land and water are two broad components on which the entire biotic community thrives. The available surface water resources are inadequate to the entire water requirements for all purposes. So the demand for ground water has increased over the years. The current and continuing drought in many parts of the world, combined with ever increasing demands from both traditional and new water users, including municipal, industrial, agricultural and environmental needs, has impacted groundwater resources.

Underground water pollution is progressively emerging as a serious challenge in different countries in Europe, Asia and Africa. It gained international scientific interest during the last decades and has been studied using several approaches and techniques. The vulnerability of ground water qualitatively reflects the natural ability of the aquifer to be reached and affected by pollution from surfaces (landfill, industrial wastewater discharge, chemical fertilizers, pesticides, herbicides etc) (Sadkaoui et al. 2013). Electrical resistivity surveys have been used for many decades in hydro-geological, mining and geotechnical investigations. More recently, it has been used for environmental surveys. A number of geophysical exploration techniques are available which enables an insight to be obtained rapidly in the nature of water bearing layers and include geo-electric, electromagnetic, seismic and geophysical borehole logging (Alile, et al. 2008). These methods measure properties of formation materials, which determine whether such formation may be sufficiently porous and permeable to serve as an aquifer. The electrical resistivity method and seismic refraction method are the surface geophysical methods commonly used for groundwater exploration (Asawa, 2009). The protection of groundwater reservoir is given by the covering layers, also called protective layers. An effective groundwater protection is given by protective layers with sufficient thickness and low hydraulic conductivity (Aweto, 2011). It depends on the aquifer characteristics as well as the geological and hydrological environment. Specific vulnerability is determined by the aquifer intrinsic vulnerability and the contaminant loading that is applied to the specific point of the hydro-geological basin. The present study involves the use of electrical resistivity method to assess the vulnerability of aquifers using geo-electric parameters of the near-surface materials overlying the aquifer. This method is much easier, it is a well-established method, the equipment is inexpensive, mobile, easy to operate, provides relatively rapid areal coverage with the depth of penetration limited only by the ability to extend electrode spacing (U.S. Environmental Protection Agency, 2006). From the time the study area became the seat of government power (i.e the state capital) for the state, there has been enormous migration of people 
to the town. The increase in population and urbanization in Location and Geology

the study area puts the groundwater resources at risk. The study area Uyo, AkwaIbom State is located in the Since potable surface water is not readily available in the southern part of Nigeria between latitude $5^{\circ} 05^{\prime}$ North to study area, the alternative is to depend on groundwater $4^{\circ} 55^{\prime} \mathrm{N}$ and longitude $8^{\circ} 00^{\prime}$ East to $7^{\circ} 50^{\prime}$ East. source. Hence the major source of water in the study area Geologically, the study area belongs to the area classified is groundwater resource. There is need for constant as coastal plain sands known as the Benin Formation monitoring and evaluation of the water resources in the (Mbipom et al., 1996). The Benin Formation is the region to prevent occurrence of epidemics and to adopt uppermost unit of the Niger Delta Complex and overlies appropriate water management strategies. Hence this study the Agbada Formation. The Benin Formation is the aims at assessing with the use of electrical resistivity youngest formation of the Niger Delta sedimentary basin. method the vulnerability of aquifer in the region to The essential features of the Benin formation have been contamination. reviewed by various authors: (Akpabio et al, 2003; Short and Stauble, 1967).

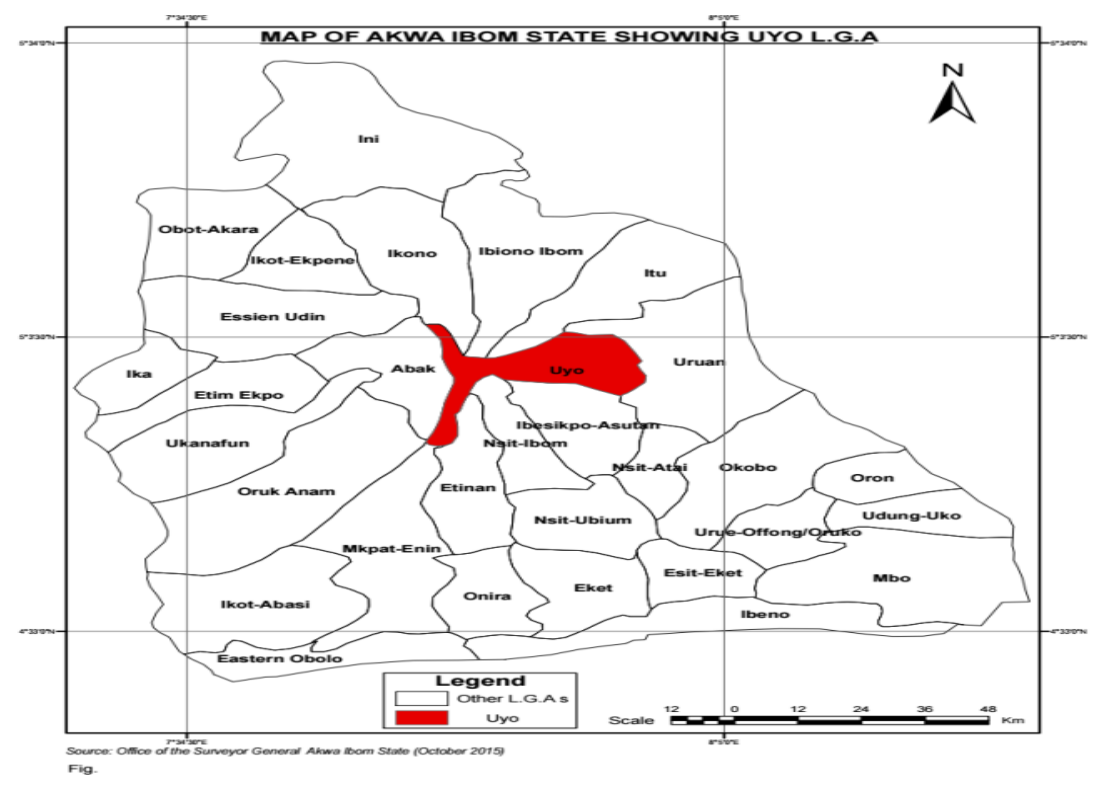

\section{MATERIALS AND METHOD}

Geoelectric sounding (VES) surveys in the area were the final curves. The Hemkler program computes conducted using ABEM Terrameter Self Averaging resistivity and depth value at each measurement point. The System (SAS) which apparent resistivity values can be Golden SURFER 8.2 was used to produce the aquifer computed from Ohm's law.Seventeen electrical resistivity vulnerability map of the study area. Thirteen (13) vertical soundings were carried out with the Terrameter SAS 300B electrical sounding (VES) points were conducted at using the schlumberger electrode configuration. The total various locations within the study area in order to study current electrode probe varied from $400 \mathrm{~m}$ to $800 \mathrm{~m}$ the variations in the resistivity distribution of the soil with depending on the access roads, topography, human depth. GPS device was used for measuring the spatial settlement and general infrastructure. In other to convert location (latitude and longitude) for the VES points (Table the resistance reading to an apparent ground resistivity, a 2).

geometric factor was applied to the data, based on the Groundwater potential and aquifer vulnerability studies schlumberger configuration used in this study. The (Golam et al. 2014; Oborie and Udom, 2014). High apparent resistivity data were plotted against current longitudinal conductance values usually indicate relatively electrodes separation and interpreted quantitatively. high protective capacity and should be accorded the Computer-aided interpretation of the field data was done highest priority in terms of groundwater vulnerability in two stages. In the first stage, all the manually assessment. The total longitudinal conductance (S) for smoothened sounding curves were subjected to forward each of geoelectric sounding (VES) stations was computed modeling techniques run by Schlumberger sounding data from the relation:

processing and interpretation program, version 1.82 (Zhody and Bisdorf, 1989). This process yielded the initial estimates of the resistivity of the various geo-electric layers in assumed layered models for the computer iterative least-square inversion. A VES modeling for Schlumberger Automatic Analysis, version 0.92 (S.A.A.V.0.92) developed by Hemkler in 1985 was used to obtain

$$
\mathrm{S}=\Sigma(\mathrm{hi} / \rho \mathrm{i})=\mathrm{h} 1 / \rho 1+\mathrm{h} 2 / \rho 2+\ldots+\mathrm{hn} / \mathrm{\rho n}
$$

Where $\mathrm{S}$ is the total longitudinal conductance, $\Sigma$ is summation sign, hi is the thickness of the ith Layer and $\rho i$ is the resistivity of the ith layer. The total longitudinal conductance $(\mathrm{S})$ values computed were plotted and contoured to produce the aquifer vulnerability map. 


\section{RESULTS AND DISCUSSIONS}

\subsection{Geo-electric Sections}

The most important parameter in quantitative interpretation is the depth of the aquiferous units. Depth to water information is contained in the interpretation of the

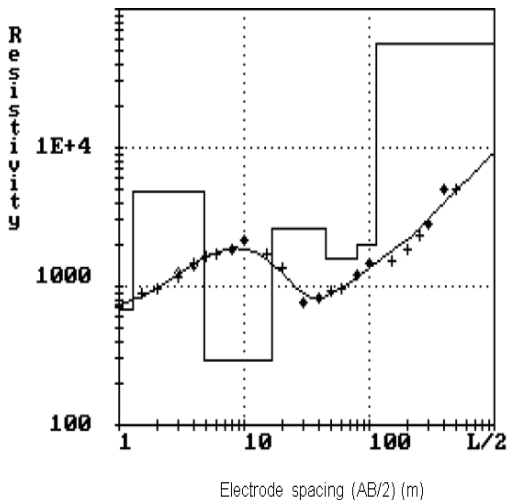

(a)

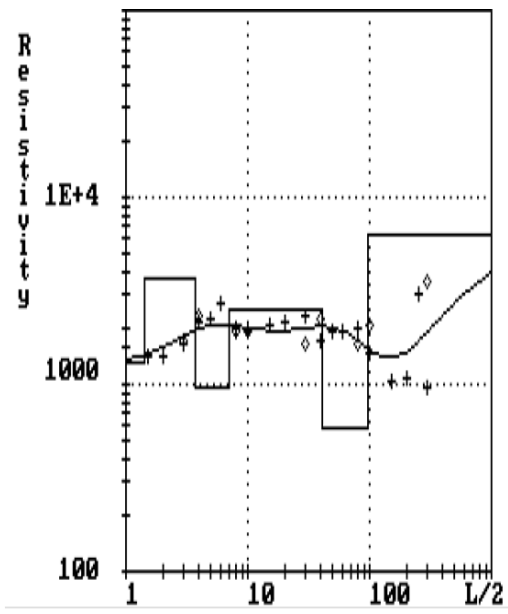

(c)

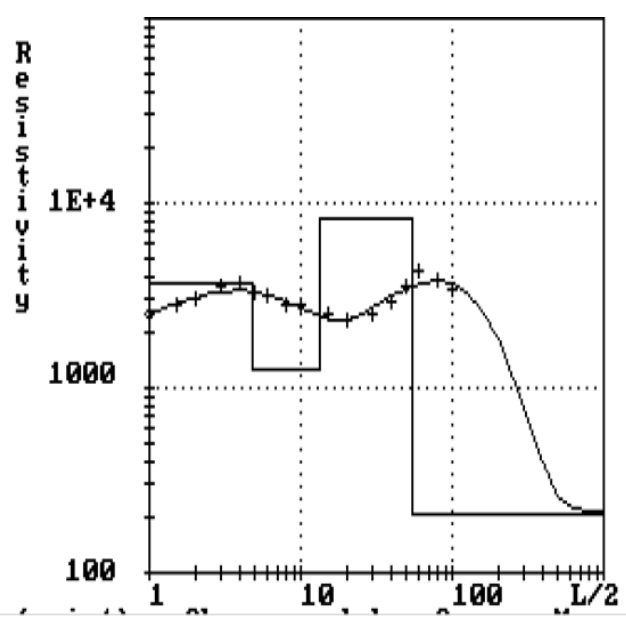

(e) geo- electric curves. In VES 1 the sounding encountered six geo- electric units: top soil, coarse sand, clayed sand, fine sand, water saturated sand and fine sand. Furthermore, Fig. 2 is a typical interpretation results of geo-electric sounding data acquired in the area (VES 1, 4, 7, 10, 12 and 15)

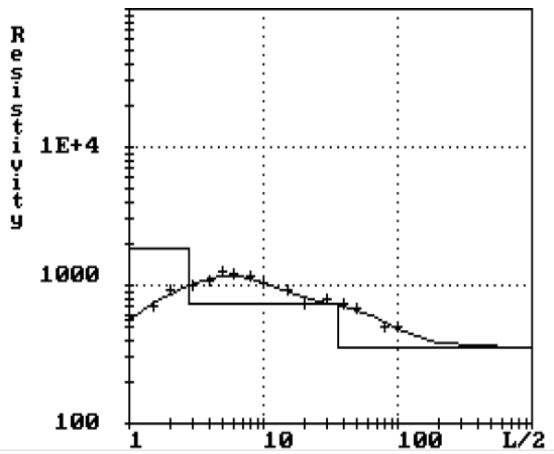

(b)

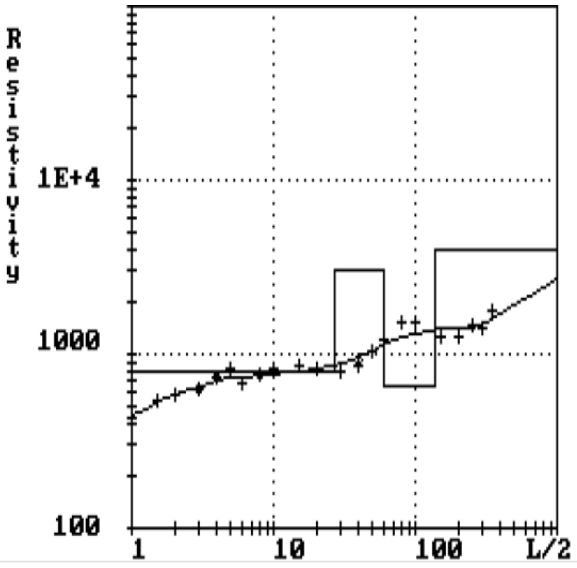

(d)

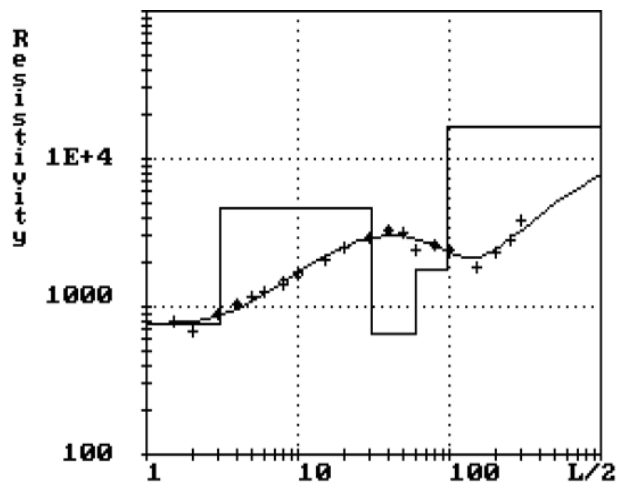

(f)

Fig 2: Typical interpretation results of geo-electric sounding data acquired in the study area (a) VES 1 (b) VES 4 (c) 7 (d) VES 10 (e) VES 12 (f) VES 15. 
3.2 Assessment of Aquifer Vulnerability

The earth is made of soil particles of different types. The earth medium acts as a natural filter to percolating fluid, the ability of the earth to filter fluid is dependent on the aquifer thickness, the covering materials and the protective capacity of the overlying overburden of the aquifer. Silts and clays are suitable aquitards which often constitute protective geologic barriers and when they are found above an aquifer they constitute a protective cover (Lenkey et al. 2005), they thus protect the aquifer from surface and near-surface contamination, because their low hydraulic conductivity leads to high residence time of percolating water. Table1 presents longitudinal conductance/protective capacity ratings. The table enables the classification of the study area into various grades. The areas that are classified weak and poor are most susceptible to contamination, while the good, very good and excellent classification indicates high protective geological formation to contamination.

Table 1: Longitudinal Conductance/Protective Capacity Rating (Ogungbemi et al. 2013)

\begin{tabular}{|l|l|}
\hline Longitudinal Conductance (mhos) & Protective Capacity Ratings \\
\hline$>10$ & Excellent \\
\hline $5-10$ & Very Good \\
\hline $0.7-4.9$ & Good \\
\hline $0.2-0.69$ & Moderate \\
\hline $0.1-0.19$ & Weak \\
\hline$<0.1$ & Poor \\
\hline
\end{tabular}

Sandy overburden has been reported by several authors to study area, ranges from0.003864 to $0.059655 \mathrm{mhos}$. The be characterized by relatively low longitudinal results of assessment of the aquifer vulnerability (Table 2) conductance, which offers very little protection to the shows that the protective capacity at the study area is poor, underlying aquifer (Golam et al. 2014; Anomohanran, these regions are characterized by thin or no shale or clay 2013; Rădulescu, et al. 2006). Table 2 shows the soil layers, it therefore implies that the aquifer in these layers, geo-electrical resistivity, aquifer thickness, locations are vulnerable to contamination. This is as a lithology, longitudinal conductance and the protective result of the type of the soil formation within the study capacity of the VES points. The study area lithology is area, which is predominantly sandy in nature (Mbipom et characterized with sand, fine and coarse with very little al., 1996). Moreover, sandy soils have a larger pore space clay deposit. Protective layers in this study seem to offer which enables easy passage of water, hence they are lower longitudinal conductance in the absence of clay. The vulnerable compared to clayed to clay and shale longitudinal unit conductance (S) values obtained from the (Chukwuma et al., 2015).

Table 2: Geo-electric parameters, lithological delineation and protective capacity of the study area

\begin{tabular}{|c|c|c|c|c|c|c|}
\hline $\begin{array}{l}\text { VES } \\
\text { No. }\end{array}$ & Layers & $\begin{array}{l}\text { Resistivity } \\
\text { (ohm-m) }\end{array}$ & $\begin{array}{l}\text { Thickness } \\
\text { (m) }\end{array}$ & Lithology & $\begin{array}{l}\text { Longitudinal } \\
\text { Conductance }\end{array}$ & $\begin{array}{l}\text { Protective } \\
\text { Capacity }\end{array}$ \\
\hline \multirow[t]{5}{*}{1} & 1 & 695 & 0.48 & Top sand & 0.000691 & \multirow{5}{*}{$\begin{array}{c}0.059655 \\
\text { (Poor) }\end{array}$} \\
\hline & 2 & 4900 & 4.52 & Coarse sand & 0.000922 & \\
\hline & 3 & 290 & 12.48 & Clayed sand & 0.043034 & \\
\hline & 4 & 2500 & 37.52 & Fine sand & 0.015008 & \\
\hline & 5 & 1700 & 43.80 & Saturated sand & & \\
\hline \multirow{4}{*}{2} & 1 & 800 & $20 \Omega 0$ & Tonond & 0026250 & \multirow{4}{*}{$\begin{array}{c}0.046583 \\
\text { (Poor) }\end{array}$} \\
\hline & 1 & 800 & 29.00 & Top sand & 0.036250 & \\
\hline & 2 & 3000 & 31.00 & Fine sand & 0.010333 & \\
\hline & 3 & 700 & 119.00 & Saturated Sand & & \\
\hline & & & & & & \\
\hline & & & & & & \multirow{4}{*}{$\begin{array}{c}0.003864 \\
\text { (Poor) }\end{array}$} \\
\hline \multirow[t]{3}{*}{3} & 1 & 2200 & 7.80 & Top Sand & 0.003545 & \\
\hline & 2 & 32000 & 10.20 & Coarse Sand & 0.000319 & \\
\hline & 3 & 1800 & 59.80 & Saturated Sand & & \\
\hline \multirow[t]{3}{*}{4} & 1 & 1900 & 2.90 & Top Sand & 0.001526 & \multirow{3}{*}{$\begin{array}{c}0.040526 \\
\text { (Poor) }\end{array}$} \\
\hline & 2 & 900 & 35.10 & Sand & 0.039000 & \\
\hline & 3 & 320 & & Saturated Sand & & \\
\hline \multirow[t]{2}{*}{5} & 1 & 2900 & 2.80 & Top Sand & 0.000966 & \multirow{2}{*}{$\begin{array}{c}0.029148 \\
\text { (Poor) }\end{array}$} \\
\hline & 2 & 220 & 6.20 & Clayed Sand & 0.028182 & \\
\hline
\end{tabular}


IARJSET

International Advanced Research Journal in Science, Engineering and Technology

Vol. 3, Issue 1, January 2016

\begin{tabular}{|c|c|c|c|c|c|c|}
\hline & 3 & 1600 & 153.80 & Saturated Sandstone & & \\
\hline \multirow[t]{4}{*}{6} & 1 & 5000 & 2.80 & Top Sand & 0.000560 & \multirow{4}{*}{$\begin{array}{c}0.006281 \\
\text { (Poor) }\end{array}$} \\
\hline & 2 & 1800 & 6.20 & Fine sand & 0.003444 & \\
\hline & 3 & 6500 & 14.80 & Coarse sand & 0.002277 & \\
\hline & 4 & 500 & 27.20 & Saturated Sand & & \\
\hline \multirow[t]{5}{*}{7} & 1 & 1500 & 1.55 & Top sand & 0.001033 & \multirow{3}{*}{$\begin{array}{c}0.016323 \\
\text { (Poor) }\end{array}$} \\
\hline & 2 & 4900 & 2.25 & Coarse sand & 0.000459 & \\
\hline & 3 & 998 & 4.75 & Fine sand & 0.004760 & \\
\hline & 4 & 3500 & 35.25 & Coarse sand & 0.010071 & \\
\hline & 5 & 600 & 64.75 & Saturated Sand & & \\
\hline \multirow[t]{4}{*}{8} & 1 & 500 & 1.30 & Top Soil & 0.002600 & \multirow{4}{*}{$\begin{array}{c}0.012859 \\
\text { (Poor) }\end{array}$} \\
\hline & 2 & 750 & 3.60 & Fine sand & 0.004800 & \\
\hline & 3 & 8500 & 46.40 & Coarse sand & 0.005459 & \\
\hline & 4 & 310 & 101.60 & Saturated Sand & & \\
\hline \multirow[t]{4}{*}{9} & 1 & 2500 & 2.00 & Top Sand & 0.000800 & \multirow{4}{*}{$\begin{array}{c}0.009300 \\
\text { (Poor) }\end{array}$} \\
\hline & 2 & 1000 & 3.00 & Fine sand & 0.003000 & \\
\hline & 3 & 4000 & 22.00 & Coarse sand & 0.005500 & \\
\hline & 4 & 600 & 33.00 & Saturated Sand & & \\
\hline \multirow{3}{*}{10} & 1 & 800 & 2800 & Ton Sand & 0035000 & \multirow{3}{*}{$\begin{array}{c}0.045667 \\
\text { (Poor) }\end{array}$} \\
\hline & 2 & 3000 & 32.00 & Fine sand & 0.010667 & \\
\hline & 3 & 650 & 118.00 & Saturated Sand & & \\
\hline \multirow[t]{5}{*}{11} & 1 & 2800 & 1.60 & Top Sand & 0.000571 & \multirow{5}{*}{$\begin{array}{c}0.017337 \\
\text { (Poor) }\end{array}$} \\
\hline & 2 & 190 & 1.20 & Clayed Sand & 0.006316 & \\
\hline & 3 & 19000 & 13.80 & Coarse sand & 0.000726 & \\
\hline & 4 & 2900 & 28.20 & Fine sand & 0.009724 & \\
\hline & 5 & 500 & & Saturated Sand & & \\
\hline \multirow[t]{4}{*}{12} & 1 & 3900 & 4.90 & Top Sand & 0.001256 & \multirow{4}{*}{$\begin{array}{c}0.013994 \\
\text { (Poor) }\end{array}$} \\
\hline & 2 & 1300 & 9.10 & Fine sand & 0.007000 & \\
\hline & 3 & 8000 & 45.90 & Coarse sand & 0.005738 & \\
\hline & 4 & 220 & & Undefined & & \\
\hline \multirow{5}{*}{13} & & 2000 & 105 & Ton Sand & 0000075 & \multirow{5}{*}{$\begin{array}{c}0.013994 \\
\text { (Poor) }\end{array}$} \\
\hline & 1 & 2000 & 1.93 & 1op sand & 0.000915 & \\
\hline & 2 & 700 & 6.55 & Sand & 0.009357 & \\
\hline & 3 & 5200 & 33.45 & Coarse sand & 0.006433 & \\
\hline & 4 & 1500 & 76.55 & Saturated fine sand & & \\
\hline \multirow[t]{3}{*}{14} & 1 & 900 & 9.00 & Top Sand & 0.010000 & \multirow{3}{*}{$\begin{array}{c}0.015897 \\
\text { (Poor) }\end{array}$} \\
\hline & 2 & 3900 & 23.00 & Coarse sand & 0.005897 & \\
\hline & 3 & 590 & 77.00 & Saturated Sand & & \\
\hline \multirow[t]{3}{*}{15} & 1 & 790 & 3.00 & Top Sand & 0.003797 & \multirow{3}{*}{$\begin{array}{c}0.009307 \\
\text { (Poor) }\end{array}$} \\
\hline & 2 & 4900 & 27.00 & Coarse sand & 0.005510 & \\
\hline & 3 & 670 & 33.00 & Saturated Sand & & \\
\hline \multirow[t]{3}{*}{16} & 1 & 800 & 29.00 & Top Sand & 0.036250 & \multirow{3}{*}{$\begin{array}{c}0.046917 \\
\text { (Poor) }\end{array}$} \\
\hline & 2 & 3000 & 32.00 & Coarse sand & 0.010667 & \\
\hline & 3 & 630.00 & 118.00 & Saturated Sand & & \\
\hline 17 & 1 & 2800 & 1.60 & Top Sand & 0.000571 & 0.008008 \\
\hline & 2 & 390 & 2.30 & Clayed sand & 0.005897 & (Poor) \\
\hline & 3 & 5000 & 7.70 & Coarse sand & 0.001540 & \\
\hline & 4 & 920 & 64.30 & Saturated fine sand & & \\
\hline
\end{tabular}




\section{International Advanced Research Journal in Science, Engineering and Technology}

Vol. 3, Issue 1, January 2016

By using the resistivity values measured from the geo- conductance (Figure 3), which gives detailed information electric survey, longitudinal unit conductance of the on the pattern of the protective capacity of the natural overlying overburden was evaluated. Vulnerability map of overburden over the aquifer in the study area. the study area was produced from the longitudinal unit

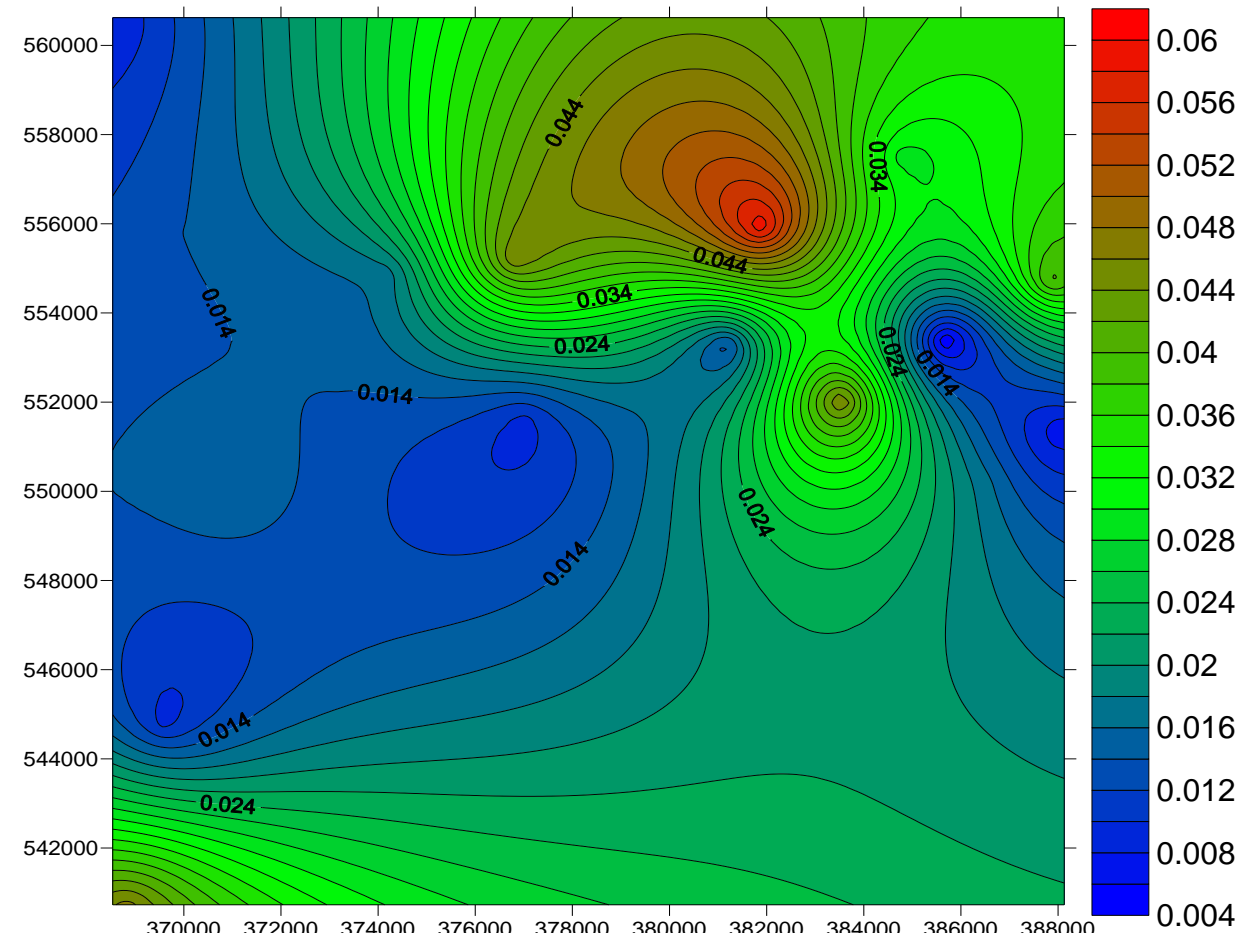

\section{CONCLUSION}

The vulnerability map shows that aquifers within the study area are vulnerable to pollution. The North central of the map though may be poor has a higher protective capacity, followed by parts of the north east, southwest and south central (VES 1,2,4,10\& 16). Southwest and northwest of 8 the map showed the lowest level of protection. In conclusion, pollution is as a result of several activities that tends to aggravates it, thus since the aquifers within the study area are susceptible to pollution, preventive measures should be taken to protect the aquifer from degradation and ensure groundwater development for quality and sustainable water supply through instrumental approach, community participation and adaptive measures.

\section{REFRENCES}

1. Akpabio, I. O., Ejedawe, J. E., Ebeniro, J. O. and Uko, E. D (2003): Geothermal gradient in the Niger Delta fromcontinuous temperature logs. Global Journal of Pure and Applied Sciences 2003; V. 9 (No. 2): 265-271.

2. Alile MO, Amadasun CVO, andEvbuomwan AI (2008): Application of Vertical Electrical Sounding Methodto Decipher the Existing Subsurface Stratification and Groundwater Occurrence Status in a Location in Edo North of Nigeria. International Journal of Physical Sciences 2008; 3(10):245-249.

3. Anomohanran O.(2013): Geoelectrical investigation of groundwater condition in Oleh, Nigeria.Www. arpapress.com.IJRRAS2013; 15(1)1:5.

4. Anudu GK, Onuba LN, and Ufondu LS. (2011): Geo-electric sounding for Groundwater Exploration in The Crystalline Basement Terrain around Onipe and Adjoining Areas, Southwestern Nigeria. Journal of applied Tech. In Environmental Sanitation. 2011; 1(4):343-354.

5. Asawa GL. (2009): Irrigation and Water Resources Engineering. New Delhi, New Age International Limited Publishers, 2009.

6. Aweto KE. (2011): Aquifer vulnerability assessment at Oke-Ila area, Southwestern Nigeria. International Journal of the Physical Sciences 2011; 6(33):7574 - 7583.
7. Chukwuma E.C., Orakwe L.C., Anizoba D.C., Amaefule D.O., Odoh C.C. and Nzediegwu C. (2015): Geo-electric Groundwater Vulnerability Assessment of Overburden Aquifers at Awka in Anambra State, South-Eastern Nigeria. European Journal of Biotechnology and Bioscience 2015; 3 (1): 29-34.

8. Dobrin, M.D, and Ring RF. (1976): Introduction to Geophysical Prospecting. New York, McGraw-Hill Brook, 1976 [6].

9. Golam SS, Keramat M, and Shahid M. (2014): Deciphering transmissivity and hydraulic conductivity of the aquifer by vertical electrical sounding (VES) experiments in Northwest Bangladesh, Appl Water Sci, 2014.

10. Koefoed O.(1979): Geo-sounding Principles: Resistivity Sounding Measurements. Armsterdam: Elsevier Scientific Publishing Company, 1979.

11. Lenkey L, Hamori Z, and Mihalffy P. (2005): Investigating the hydrogeology of a water-supply area using direct-current vertical electrical soundings. Geophy 2005; 70(4):1-19.

12. Mbipom, E. N., E. E. Okwueze and A. A. Onwegbuche, (1996). Estimation of transmissivity using VES data from the Mbaise area of Nigeria. Niigeria Journal of Physics, V. 85, pp 28-32

13. Oborie E1, and Udom GJ. (2014: Determination of aquifer transmissivity using geoelectrical sounding and pumping test in parts of Bayelsa State, Nigeria. Peak Journal of Physical and Environmental Science Research 2014; 2(2):32-40.

14. Odumodu OI. And Ekenta EO. (2012): Modelling Operation and Maintenance Management of Water Supply in Awka, Anambra State, Nigeria. Journal of Emerging Trends in Engineering and Applied Sciences (JETEAS) 2012; 3(5):868-873.

15. Ogungbemi OS, Badmus GO, Ayeni OG, and Ologe O. (2012): Geo- electric Investigation of Aquifer Vulnerability within AfeBabalola University, Ado-Ekiti, Southwestern Nigeria. Journal of Applied Geology and Geophysics, 2013; 1(5):28-34.

16. Rădulescu V, Rădulescu F, and Stan L. (2006): Geoelectrical Measurements Applied to the Assessment of Groundwater Quality. GEO-ECO-MARINA, 2006.

17. US. Environmental Protection Agency (EPA). (2006): Drinking water contaminants, 2006. http://www.epa.gov/safewater/ contaminants/index.html. 